\title{
Impact of hydropower dam on total suspended sediment and total organic nitrogen fluxes of the Red River (Vietnam)
}

\author{
Nhu Da Le ${ }^{1,2}$, Thi Phuong Quynh Le ${ }^{1,2}$, Thi Xuan Binh Phung ${ }^{3}$, Thi Thuy Duong ${ }^{4}$, and Orange Didier ${ }^{5}$ \\ ${ }^{1}$ Graduate University of Science and Technology, 18 Hoang Quoc Viet road, \\ Cau Giay district, Hanoi city, Vietnam \\ ${ }^{2}$ Institute of Natural Product Chemistry, Vietnam Academy of Science and Technology, \\ 18 Hoang Quoc Viet road, Cau Giay district, Hanoi city, Vietnam \\ ${ }^{3}$ Electric Power University, 235 Hoang Quoc Viet, Bac Tu Liem, Hanoi, Vietnam \\ ${ }^{4}$ Institute of Environmental Technology, Vietnam Academy of Science and Technology, 18 Hoang Quoc Viet \\ road, Cau Giay district, Hanoi city, Vietnam \\ ${ }^{5}$ IRD, ECO\&SOLS, University of Montpellier, CIRAD, INRA, Supagro Montpellier, Place Viala, 34060 \\ Montpellier CEDEX 2, France
}

Correspondence: Le Thi Phuong Quynh (quynhltp@gmail.com, quynhltp@yahoo.com) and Le Nhu Da (dalenhu@gmail.com)

Published: 16 September 2020

\begin{abstract}
The Red River is a typical example of the Southeast Asian rivers, which has been strongly affected by human activities. This paper analyses the change of total suspended sediment (TSS) load of the Red River from 1960 to 2015 in which numerous new dams in both China and Vietnam have been constructed. A strong decrease of TSS load of the whole Red River (from $79 \pm 26 \times 10^{6} \mathrm{t} \mathrm{yr}^{-1}$ in 1960s to $6 \pm 1 \times 10^{6} \mathrm{t} \mathrm{yr}^{-1}$ in 2010s) allocated to the dam impoundments in spite of population and deforestation increase. Base on the experimental equation describing the relationship between TSS and total organic nitrogen (TON) concentrations, and on the available data of TSS concentration and river discharge, the longterm TON concentrations and fluxes were calculated for the three tributaries and the whole Red River. The annual average of TON concentrations spatially varied from 0.41 to $3.19 \mathrm{mg} \mathrm{L}^{-1}$, averaging $0.98 \mathrm{mg} \mathrm{L}^{-1}$ for the whole period; the lowest was found for the Da River where the new dams have been impounded. The highest TON concentrations and fluxes occurred in the wet season in relationship with the highest sediment loads and river discharges. The riverine TON fluxes transferred to estuary significantly decreased from $141 \times 10^{3} \pm 38 \times 10^{3} \mathrm{t} \mathrm{yr}^{-1}$ (equivalent to $902 \pm 247 \mathrm{~kg} \mathrm{~km}^{-2} \mathrm{yr}^{-1}$ ) in 1960 s to $32 \times 10^{3} \pm 5 \times 10^{3} \mathrm{tyr}^{-1}$ (equivalent to $207 \pm 35 \mathrm{~kg} \mathrm{~km}^{-2} \mathrm{yr}^{-1}$ ) in $2010 \mathrm{~s}$. The TSS flux decrease has driven a clear reduction of associated elements like nitrogen, which let to hypothesis a change in biogeochemical processes in the coastal zone.
\end{abstract}

\section{Introduction}

Total suspended solids (TSS) transported by the Asian rivers to the coastal ocean play an important role in the global delivery of TSS and associated elements $(\mathrm{C}, \mathrm{N}, \mathrm{P})$ due to the significant quantities of suspended solids. However, in recent decades, TSS and material fluxes of these rivers have been altered drastically as a result of reservoir impound- ment, land use, population, and climate change (Walling and Fang, 2003). Within the factors affected to the riverine TSS load, dams and reservoirs are known to be the most important. The impact of dam impoundment was clearly observed for numerous Asian Rivers such as the Yangtze River (Changjiang) (Wu et al., 2007), the Yellow River (Huanghe) (in China) (Wang et al., 2007; Hu et al., 2015), the Mekong River (Kummu and Varis, 2007)... Dam impoundment has 
reduced TSS fluxes of these rivers by more than half. The loss of sediment and associated nutrient fluxes from the continent has dramatically affected deltas (Syvitski and Saito, 2007). The habitats of many aquatic species in coastal zone have significantly impacted the recovery of the mangroves and coastal aquaculture area. Thus, Beusen et al. (2005) emphasized that it is important to understand the response of riverine TSS and associated nutrient fluxes to regional and global changes, and the main factors that control the fluvial sediment transport to the oceans.

The Red River (Vietnam and China) is a typical Asian river which is strongly impacted by both climate and human activities. Indeed, human activities have altered the hydrology, suspended sediment and associated element (C, N, P) loads of the Red River though dam impoundment, land use change and population increased (Le et al., 2015). Two large dams (Hoa Binh, Thac Ba) have been impounded in the Red River systems, in the Vietnamese territory since 1970s. And recently, since the year 2010, new series of dams have been set up in the Red River upstream in period 2000-2015 in both China and Vietnam sectors. This study firstly aims to estimate the recent change of TSS flux due to new series of dams constructed in both China and Vietnam in the period 19602015 basing a data set of daily TSS concentrations and daily river discharge. And then, basing on the experimental equation describing the relationship between the TSS and total organic nitrogen (TON) concentrations, and on the available data of TSS concentrations and river discharges, the longterm TON concentrations and fluxes were calculated for the three tributaries and the whole Red River.

\section{Site description and methodology}

\subsection{Site description}

\subsubsection{The Red River basin}

The Red River situates in South-East Asia, drains a watershed area of $156451 \mathrm{~km}^{2}, 50.3 \%$ of which is situated in Vietnam, $48.8 \%$ in China and $0.9 \%$ in Laos. The Red River includes three tributaries Thao, Da, Lo Rivers which join at Viet Tri city, and then forms a large delta before flowing into the South-East Asian Sea through four distributaries called, Ba Lat, Lach Gia, Tra Ly and Day (Dang, 2000) (Fig. 1).

There are two distinct seasons in the Red River basin: rainy season (May-October) and dry season (NovemberApril). The annual rainfall strongly varies from 700 to $4800 \mathrm{~mm} \mathrm{yr}^{-1}$ across the basin with about $80 \%$ of rainfall occurring during the rainy season. Noted that highest incidence of typhoons occur in July and August in the basin area.

The three upstream sub-basins of Thao, Da and Lo rivers have differences in their lithology. The Red main channel basin is dominated by metamorphic rocks, except in the upper reaches where the Mesozoic sedimentary deposits are found. The Da drainage basin is composed of sedimentary rocks from the Mesozoic and Paleozoic period with minor felsic intrusions. The Lo drainage has low-grade metamorphic rocks and Proterozoic to Paleozoic sedimentary rocks with some granitic intrusions. In the central Red River Delta, silt and clay are the most abundant sediments while fine sand presents in small amounts from the Holocene succession (Moon et al., 2007).

Land use and population density are different for the four sub-basins of the Red River. Low population $\left(<100\right.$ inhabitant $\left.\mathrm{km}^{-2}\right)$ and high proportion of forestland are found for the Da river basin. The moderate population and industrial-agricultural and forest land is observed in the Lo and Thao river basins. Very high population ( $>1000$ inhabitant $\mathrm{km}^{-2}$ ) and high proportion of agricultural land are characterized for the Delta area. Change in landuse (deforestation and intensive agricultural land) and population increased for longterm period from 1960s-2010s have been revealed in a recent study (Le et al., 2015, 2018).

\subsubsection{Hydrology and Reservoir impoundment}

Hydrology

Daily river discharges at the outlets of the three tributaries Thao (at Yen Bai station), Da (at Hoa Binh station) and Lo (at Vu Quang station) and of the downstream main axe of the Red River (at Hanoi station) were available for the period 1960-2015 (MONRE, 1960-2015) (Fig. 1). The river discharge follows the variation of rainfall during the year with clear higher river discharges observed in the rainy season than in the dry one. The average river discharge of the Thao (at Yen Bai), Da (at Hoa Binh), Lo (at Vu Quang) and in the main axe at Hanoi stations were 720; 1670; 1020 and $2500 \mathrm{~m}^{3} \mathrm{~s}^{-1}$ respectively for the period $1960-2015$ (MONRE, 1960-2015). Of the three upstream tributaries, the Da River accounts for a half of the total Red River discharge. Long-term data on the decade average of water discharge showed a clear decrease for the Thao, Da tributaries and for the main downstream Red River in the 1960-2015 period (Table 1). During the whole study period, extreme low river discharges of the main axe Red River at Son Tay $\left(368 \mathrm{~m}^{3} \mathrm{~s}^{-1}\right.$ in May 1960 or $380 \mathrm{~m}^{3} \mathrm{~s}^{-1}$ in March 2002) hydrological stations were observed (Quach, 2011; Pham et al., 2015) and extreme high river discharge $\left(37800 \mathrm{~m}^{3} \mathrm{~s}^{-1}\right)$ at Son Tay station was observed in August 1971.

\section{Dam impoundment}

In the Red River basin in both China and Vietnam territory, a series of reservoirs and dams have been constructed and operated (Ha and $\mathrm{Vu}, 2012$; Le et al., 2018) for multipurpose including generating hydropower, controlling floods, providing water for the agricultural land, regulating water resource during dry season for downstream. In the upstream Thao River, two main intercepting dams (namely Namsha and Madushan, $140 \mathrm{~km}$ from the Vietnamese border to 


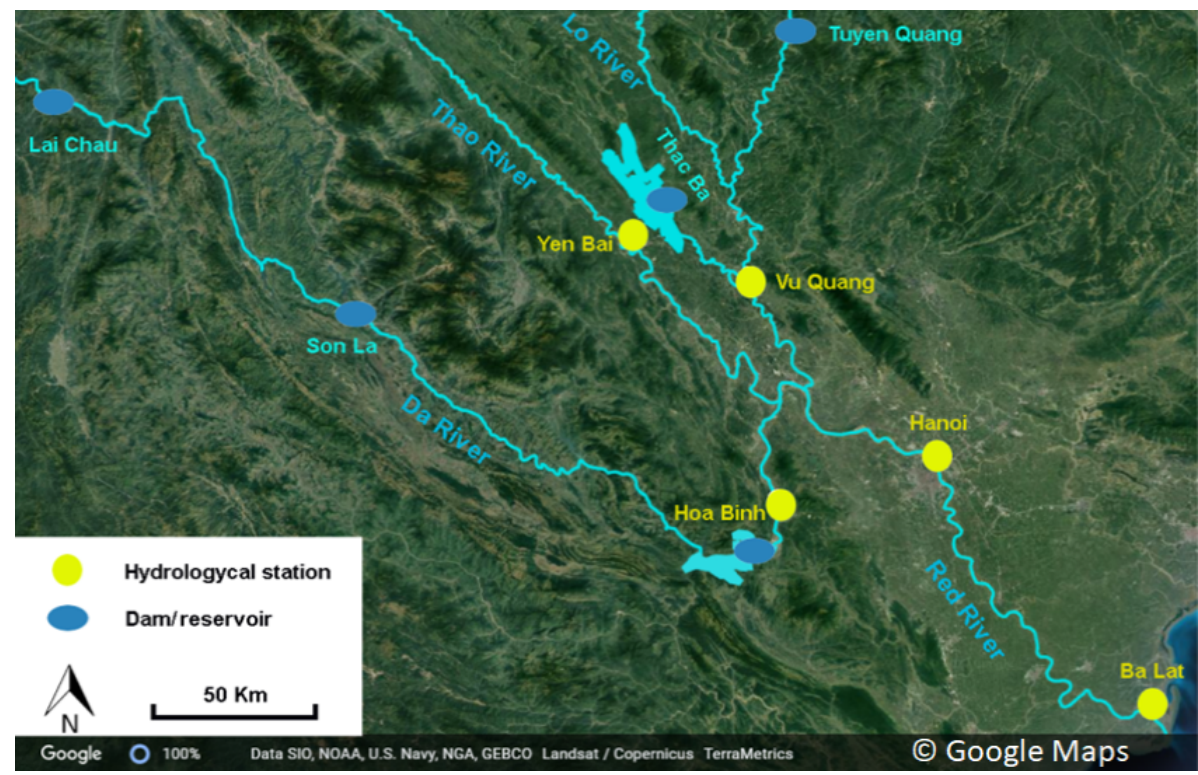

Figure 1. The Red River and its tributaries: location of the large reservoirs and hydrological stations.

Table 1. Decade average and standard deviation (SD) of river discharge, TSS and TON concentrations (mg L $\mathrm{L}^{-1}$ ) of the Thao, Da and Lo tributaries and of the main axis of the Red River at Hanoi station in different periods from 1960 to 2015.

\begin{tabular}{|c|c|c|c|c|c|c|c|c|}
\hline $\begin{array}{l}\text { Hydrological } \\
\text { station }\end{array}$ & River & Variables & 1960-1969 & $1970-1979$ & 1980-1989 & 1990-1999 & 2000-2009 & $2010-2015$ \\
\hline \multirow[t]{3}{*}{ Yen Bai } & \multirow[t]{3}{*}{ Thao } & River discharge, $\mathrm{m}^{3} \mathrm{~s}^{-1}$ & $774 \pm 126$ & $818 \pm 208$ & $674 \pm 103$ & $752 \pm 137$ & $708 \pm 140$ & $517 \pm 34$ \\
\hline & & TSS concentration, $\mathrm{mg} \mathrm{L}^{-1}$ & $883 \pm 274$ & $965 \pm 79$ & $1054 \pm 454$ & $1479 \pm 344$ & $928 \pm 297$ & $278 \pm 62$ \\
\hline & & TON concentration, $\mathrm{mg} \mathrm{L}^{-1}$ & $1.5 \pm 0.4$ & $1.7 \pm 0.1$ & $1.8 \pm 0.6$ & $2.3 \pm 0.4$ & $1.6 \pm 0.4$ & $0.7 \pm 0.1$ \\
\hline \multirow[t]{3}{*}{ Hoa Binh } & \multirow[t]{3}{*}{$\mathrm{Da}$} & River discharge, $\mathrm{m}^{3} \mathrm{~s}^{-1}$ & $1720 \pm 219$ & $1706 \pm 213$ & $1544 \pm 236$ & $1840 \pm 301$ & $1798 \pm 230$ & $1276 \pm 216$ \\
\hline & & TSS concentration, $\mathrm{mg} \mathrm{L}^{-1}$ & $475 \pm 144$ & $477 \pm 75$ & $354 \pm 169$ & $74 \pm 15$ & $56 \pm 26$ & $15 \pm 6$ \\
\hline & & TON concentration, $\mathrm{mg} \mathrm{L}^{-1}$ & $1.0 \pm 0.2$ & $1.0 \pm 0.1$ & $0.9 \pm 0.2$ & $0.5 \pm 0.0$ & $0.5 \pm 0.0$ & $0.4 \pm 0.0$ \\
\hline \multirow[t]{3}{*}{ Vu Quang } & \multirow[t]{3}{*}{ Lo } & River discharge, $\mathrm{m}^{3} \mathrm{~s}^{-1}$ & $955 \pm 144$ & $1077 \pm 227$ & $1085 \pm 165$ & $1098 \pm 158$ & $897 \pm 213$ & $990 \pm 439$ \\
\hline & & TSS concentration, $\mathrm{mg} \mathrm{L}^{-1}$ & $158 \pm 28$ & $167 \pm 54$ & $163 \pm 56$ & $207 \pm 51$ & $140 \pm 53$ & $56 \pm 22$ \\
\hline & & TON concentration, $\mathrm{mg} \mathrm{L}^{-1}$ & $0.6 \pm 0.0$ & $0.6 \pm 0.1$ & $0.6 \pm 0.1$ & $0.7 \pm 0.1$ & $0.6 \pm 0.1$ & $0.5 \pm 0.0$ \\
\hline \multirow[t]{3}{*}{ Hanoi } & \multirow{3}{*}{$\begin{array}{l}\text { Main down- } \\
\text { stream Red } \\
\text { River branch }\end{array}$} & River discharge, $\mathrm{m}^{3} \mathrm{~s}^{-1}$ & $2610 \pm 317$ & $2821 \pm 380$ & $2607 \pm 439$ & $2660 \pm 390$ & $2310 \pm 310$ & $1673 \pm 262$ \\
\hline & & TSS concentration, $\mathrm{mg} \mathrm{L}^{-1}$ & $505 \pm 112$ & $554 \pm 105$ & $434 \pm 116$ & $389 \pm 74$ & $343 \pm 172$ & $77 \pm 8$ \\
\hline & & TON concentration, $\mathrm{mg} \mathrm{L}^{-1}$ & $1.1 \pm 0.1$ & $1.1 \pm 0.1$ & $1.0 \pm 0.2$ & $0.9 \pm 0.1$ & $0.8 \pm 0.2$ & $0.5 \pm 0.0$ \\
\hline
\end{tabular}

China) have been constructed in the period 2010s (IMRR, 2010). In the Lo River, the Thac Ba was constructed the earliest, in 1972 originally designed to supply water and generate hydropower (440 MW) but did not control floods. Recently, the Tuyen Quang is impounded in the Vietnamese part and at least 8 hydropower reservoirs have been built on the upstream Lo River in the Chinese part (Ha and $\mathrm{Vu}, 2012)$. In the Da River, a series of dams/reservoirs have been constructed since 1989. Besides the 3 large reservoirs (Hoa Binh, Son La and Lai Chau), small hydroelectric power stations have been set up (Ban Chat, Huoi Quang) on the Nam Mu river, a branch of the Da River in Vietnam and about 11 small hydrological dams con- structed in the Chinese part since 2007 (Ha and Vu, 2012).

\subsection{Methodology}

\subsubsection{Data collection}

Daily TSS concentrations and the daily river discharge data of the 3 main tributaries: Yen Bai station (outlet of the Thao river), Hoa Binh station (outlet of the Da river), Vu Quang station (outlet of the Lo river), and in the main axe (at Hanoi station) of the Red River (Fig. 1, Table 1) from 1960 to 2015 were obtained from the MONRE (1960-2015). Daily TSS concentrations were determined at each gauging sta- 
tion by the Vietnamese standard TCVN 6625:2000 method (MOSTE, 2000).

\subsubsection{Calculation of TSS fluxes}

Daily TSS flux at the outlet of each tributary (Thao, Da and Lo) and at Hanoi station (main downstream axe of the Red River) was calculated based on the daily TSS concentrations with the daily river discharge. Annual TSS flux export $\left(10^{6} \mathrm{tyr}^{-1}\right)$ at the outlet of the Thao, Da and Lo and at Hanoi was calculated as the sum of daily export at each tributary and at Hanoi over the course of a year. The total TSS fluxes of the whole Red River were calculated by extrapolating the flux measured at the Hanoi station taking into account the respective Delta area in the watershed.

\subsubsection{Calculation of TON concentrations and fluxes}

Previous studies revealed that riverine particulate nitrogen loads are strongly correlated with TSS loads (Ittekkot and Zhang, 1989; Ludwig and Probst, 1996). Our previous study (Le et al., 2005) demonstrated a relationship between TSS concentrations and Total organic nitrogen (TON) concentrations for the Red River water, basing on field measurements, as shown in Eq. (1):

TON $\left(\mathrm{mgL}^{-1}\right)=0.4+0.0013 \mathrm{TSS}\left(\mathrm{mgL}^{-1}\right)$

$\left(r^{2}=0.91\right)$

Recently, we have analysed about 20 Red River samples taken in Hanoi hydrological station for testing this equation and found the possibility for application of this equation. Thus, we use this equation for calculating daily TON concentrations at different stations Yen Bai (Thao River), Hoa Binh (Da River), Vu Quang (Lo River) and Hanoi in the main branch Red River for the period 1960-2015 basing on the available daily TSS concentrations at the respective stations in this period. After obtaining daily TON concentrations, daily and annual TON fluxes were calculated by the same method for TSS flux calculation.

\section{Results and discussion}

\subsection{Total suspended solids (TSS) and total organic nitrogen (TON) concentrations}

\subsubsection{Spatial and temporal variation}

TSS concentrations which varied 8 to $2144 \mathrm{mg} \mathrm{L}^{-1}$ showed spatially different variation for the three tributaries and of the main branch of the Red River (at Hanoi stations). The highest TSS was observed at Yen Bai station (Thao River) in 1986 when the big flood occurred in this river whereas the lowest value was found at Hoa Binh station (Da River) in 2015 after the Son La dam has been in operation. For the whole period 1960-2015, within the three upstream tributaries, the mean TSS concentrations were the highest at the Thao station $\left(966 \pm 432 \mathrm{mg} \mathrm{L}^{-1}\right)$ where less dams were impounded in its main course. The TSS concentrations in the Lo and Da Rivers were much lower and averaged $157 \pm 59$ and $297 \pm 554 \mathrm{mg} \mathrm{L}^{-1}$, respectively. The TSS concentration of main axe Red River at Hanoi station, averaging $411 \pm$ $170 \mathrm{mg} \mathrm{L}^{-1}$ over the period 1960-2015 was lower than the one of the Thao River due to the dilution process because of higher discharges and lower TSS concentrations of the Da and Lo Rivers than those of the Thao River (Table 1).

Regarding temporal variation, the TSS concentrations at all sites observed showed a clear decrease over the 19602015 period. Within the three tributaries, a significant decrease of TSS concentration was found for the Da River (from $475 \pm 144 \mathrm{mg} \mathrm{L}^{-1}$ in 1960 s to $15 \pm 6 \mathrm{mg} \mathrm{L}^{-1}$ in $2010 \mathrm{~s}$ ) where a series of dams were operated in its main course (Table 1). Presently (2010-2015 period), within three main tributaries, the TSS concentration of the Da river is lowest (Table 1). The Thao and the Lo showed a clear reduction of TSS concentrations (from $883 \pm 274 \mathrm{mg} \mathrm{L}^{-1}$ in 1960 s to $278 \pm 62 \mathrm{mg} \mathrm{L}^{-1}$ in $2010 \mathrm{~s}$ ) and (from $158 \pm 28 \mathrm{mg} \mathrm{L}^{-1}$ in 1960 s to $56 \pm 22 \mathrm{mg} \mathrm{L}^{-1}$ in 2010 s, respectively) (Table 1 , Fig. 2), especially in the last decade where dams have been impounded in the Thao and Lo rivers.

TON concentration followed the same spatial variation of the TSS, being highest for the Thao River $\left(1.7 \pm 0.6 \mathrm{mg} \mathrm{L}^{-1}\right)$ and lowest for the Lo River $\left(0.6 \pm 0.1 \mathrm{mg} \mathrm{L}^{-1}\right)$ over the 1960 2015 period. A reduction of TON concentrations was also observed at different stations, however, much lower in comparing with TSS concentration decrease. Indeed, TON concentrations were reduced by a haft at all sites observed (Table 1). For the whole period, the annual average of TON concentrations spatially fluctuated from 0.41 to $3.19 \mathrm{mg} \mathrm{L}^{-1}$, averaging $0.98 \mathrm{mg} \mathrm{L}^{-1}$. Presently (2010-2015 period), within three main tributaries, the TON concentration of the Da river was lowest (Table 1).

\subsubsection{Seasonal variation}

The TSS concentrations were higher in the rainy season than in dry season at all four stations during all periods observed. Indeed, over the whole period, the average TSS concentrations in the Thao, Lo and Da Rivers during the rainy season averaging $1495 \pm 744,271 \pm 112$ and $83 \pm 262 \mathrm{mg} \mathrm{L}^{-1}$ respectively were 5 times higher than the ones in dry season averaging $301 \pm 159,35 \pm 18$ and $24 \pm 48 \mathrm{mg} \mathrm{L}^{-1}$ respectively. In the main branch of the Red River, at Hanoi station, TSS concentrations were 3 times higher in the rainy season $\left(655 \pm 276 \mathrm{mg} \mathrm{L}^{-1}\right)$ than in the dry season $\left(171 \pm 90 \mathrm{mg} \mathrm{L}^{-1}\right)$. As known, most of riverine TSS fluxes of the tropical river systems have transported during the rainy season, mainly at high river discharge (Van Maren and Hoekstra, 2004). Higher rainfall in rainy season accelerates soil erosion and leaching, 

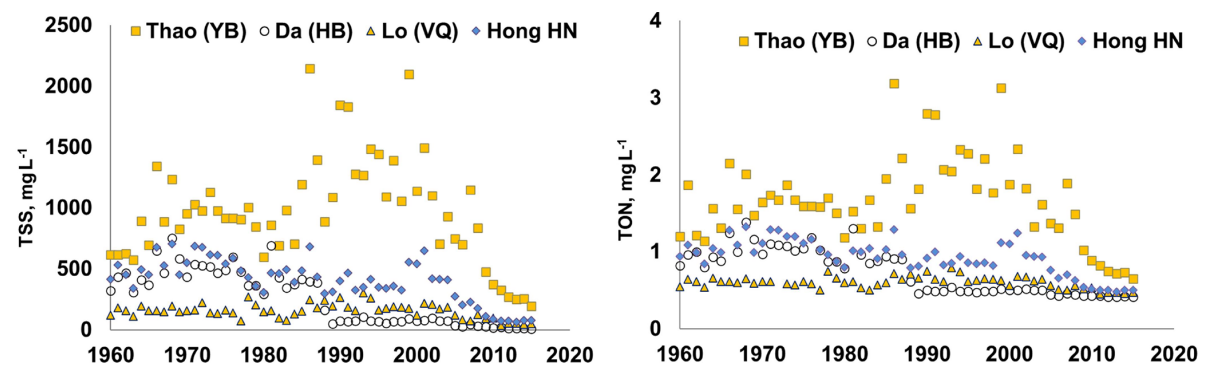

Figure 2. Annual average of TSS, TON concentrations of the Thao, Da and Lo Rivers and of the main axe at Hanoi station during different periods from 1960 to 2015 .

Table 2. Annual average and standard deviation of TSS fluxes $\left(10^{6} \mathrm{tyr}^{-1}\right)$ and TON flux $\left(10^{3} \mathrm{tyr}^{-1}\right)$ of the Thao, Da and Lo tributaries and of the whole Red River system during different periods from 1960 to 2015.

\begin{tabular}{llrrrrrr}
\hline Period & & $1960-1969$ & $1970-1979$ & $1980-1989$ & $1990-1999$ & $2000-2009$ & $2010-2015$ \\
\hline Thao (YB) & TSS & $34 \pm 18$ & $38 \pm 12$ & $36 \pm 25$ & $59 \pm 23$ & $41 \pm 21$ & $7 \pm 1$ \\
& TON & $58 \pm 25$ & $59 \pm 17$ & $55 \pm 33$ & $86 \pm 30$ & $62 \pm 28$ & $16 \pm 2$ \\
\hline Da (HB) & TSS & $57 \pm 24$ & $53 \pm 16$ & $32 \pm 19$ & $7 \pm 2$ & $5 \pm 3$ & $1 \pm 0$ \\
& TON & $95 \pm 33$ & $90 \pm 23$ & $61 \pm 27$ & $32 \pm 6$ & $29 \pm 6$ & $17 \pm 3$ \\
\hline \multirow{2}{*}{ Lo (VQ) } & TSS & $8 \pm 3$ & $10 \pm 4$ & $9 \pm 4$ & $12 \pm 3$ & $8 \pm 5$ & $2 \pm 1$ \\
& TON & $23 \pm 5$ & $27 \pm 8$ & $25 \pm 6$ & $30 \pm 5$ & $22 \pm 9$ & $15 \pm 7$ \\
\hline \multirow{2}{*}{ Whole RR } & TSS & $79 \pm 26$ & $86 \pm 22$ & $63 \pm 24$ & $58 \pm 17$ & $44 \pm 25$ & $6 \pm 1$ \\
& TON & $141 \pm 38$ & $154 \pm 33$ & $121 \pm 36$ & $114 \pm 26$ & $92 \pm 36$ & $32 \pm 5$ \\
\hline
\end{tabular}

leading to higher riverine TSS concentrations in tropical region.

Associated with TSS, TON concentrations at all sites were higher in the rainy season than in the dry season. Indeed, over the whole period, the average TSS concentrations during the rainy season in the three tributaries Thao $\left(2.5 \pm 1.0 \mathrm{mg} \mathrm{L}^{-1}\right)$, Lo $\left(0.7 \pm 0.1 \mathrm{mg} \mathrm{L}^{-1}\right)$ and $\mathrm{Da}\left(0.6 \pm 0.3 \mathrm{mg} \mathrm{L}^{-1}\right)$ Rivers and the main axe at Hanoi station $\left(1.2 \pm 0.4 \mathrm{mg} \mathrm{L}^{-1}\right)$ were about 1.5-3.0 times higher than the ones in dry season $(0.8 \pm 0.2$, $0.5 \pm 0.1 ; 0.5 \pm 0.1$ and $0.6 \pm 0.1 \mathrm{mg} \mathrm{L}^{-1}$ respectively.

\subsubsection{Total suspended solids (TSS) and total organic nitrogen (TON) fluxes}

Our calculations showed that the TSS fluxes of the Da River at the Hoa Binh hydrological station decreased significantly from $57 \times 10^{6} \pm 22 \times 10^{6} \mathrm{t} \mathrm{yr}^{-1}$ for the period 1960-1969 to $1.0 \times 10^{6} \pm 0 \times 10^{6} \mathrm{t} \mathrm{yr}^{-1}$ for the period 2000-2015 (Table 2).

Comparing with the period 1960-1969 (before the Hoa Binh reservoir presence), the TSS fluxes of the Da River in the period 1990s decreased about $87.8 \%$. Since the additional presence of the Son La, Lai Chau, Huoi Quang reservoirs in Vietnam and 11 small hydroelectric powers in China, the TSS fluxes at the outlet of the Da River further decreased at the total rate of $98.6 \%$. It clearly shows the important role of the reservoirs in TSS storage, leading to a clearly decrease of TSS fluxes at the outlet of the Da River (Table 2). For the
Lo and the Thao Rivers, similarly, in the period 2000-2015, the TSS fluxes at the outlets of these rivers decreased by $72 \%$ and $80 \%$ respectively, comparing to the pre-construction the hydropower plants in both Vietnam and China (Table 2).

Previous study found that about $70 \%$ reduction of sediment flux was observed for the Red River after the impoundment of the Hoa Binh and Thac Ba reservoirs on the Da and Lo rivers (Le et al., 2007; Dang et al., 2010). Our study revealed that actually, at Hanoi site, the TSS fluxes in the period 2010-2015 decreased by $92 \%$ in comparing with the period without reservoir impoundment in the whole Red River system (1960s) (Table 2). In addition, at Hanoi station (dowstream of the Red River), we observed that the sum of the annual TSS fluxes of the three tributaries Thao, Da and Lo (input to the Delta area) was higher than the mean annual fluxes of the Hanoi site (output). This is due to the complexity of the hydrological network in the Delta area where some distributaries flow out from the main branch of the Red River (Duong, Day and Nhue Rivers) (Luu et al., 2010) and the important deposition process in the section from the Viet Tri Son Tay - Hanoi, the floodplains (Lu et al., 2015).

Overall, the TSS fluxes of the whole Red River transferred to the estuary significantly decreased from $79 \times 10^{6} \pm$ $26 \times 10^{6} \mathrm{tyr}^{-1}$ (equivalent to a specific sediment yield of $505 \pm 166 \mathrm{t} \mathrm{km}^{-2} \mathrm{yr}^{-1}$ ) in the period 1960s to $6 \times 10^{6} \pm 1 \times$ 
$10^{6} \mathrm{tyr}^{-1}$ (corresponding to a specific sediment yield of $\left.38 \pm 6 \mathrm{t} \mathrm{km}^{-2} \mathrm{yr}^{-1}\right)$ in $2010-2015$ period.

The TSS fluxes of the Red River at present situation (2010s) were much lower than that of the large Asian Rivers such as the Ayeyarwady (1966 to 1996): $325 \times 10^{6} \mathrm{t} \mathrm{yr}^{-1}$ (Furuichi et al., 2009).

In Asia, reservoirs have been constructed on large rivers for multi-purposes, including hydropower, flood control/flow management, irrigation/water supply... The dam/reservoir impoundment resulted in dramatically reducing of sediment flux discharged to the sea which was observed for numerous Asian rivers. For example, the sediment discharge of the Yangtze River (Changjiang) decreased from $480 \times 10^{6} \mathrm{t} \mathrm{yr}^{-1}$ to approximately $150 \times 10^{6} \mathrm{tyr}^{-1}$ over a 20 -year period (Wang et al., 2008) whereas the Yellow River (Huanghe) (in China) reduced from $1080 \times 10^{6}$ to $150 \times 10^{6} \mathrm{tyr}^{-1}$ over a 40-year period (Wang et al., 2007). For some cases of Asian river, e.g the Minjiang River (Xu and Yan, 2010) and the Upper Mekong River (Kummu and Varis, 2007), different reservoirs were built in different times, and thus, the sediment trapping induced by different reservoirs has various phases, driven to the complicated effects caused by a single reservoir.

In addition, associated with riverine TSS, the reduction of TSS flux could decrease a large particulate nutrients (N, P) and carbon load to the estuary. In this study, TON load of the whole Red River reduced from $141 \times 10^{3} \pm 38 \times 10^{3} \mathrm{t} \mathrm{yr}^{-1}$ (equivalent to a specific yield of $902 \pm 247 \mathrm{~kg} \mathrm{~km}^{-2} \mathrm{yr}^{-1}$ ) in the period 1960 s to $32 \times 10^{3} \pm 5 \times 10^{3} \mathrm{t} \mathrm{yr}^{-1}$ (corresponding to a specific sediment yield of $207 \pm 35 \mathrm{~kg} \mathrm{~km}^{-2} \mathrm{yr}^{-1}$ ) in 20102015 period.

The construction of reservoirs has caused sudden loss of huge amounts of fresh water, sediment and nutrients from the rivers into the estuaries and coastal areas. Some major river systems in Asia, such as the Yellow River, the Changjiang River, the Mekong River, ... have significant decreases in water flow and suspended solid load due to environmental changes, especially the human impacts in recent decades (Lu and Siew, 2006; Kummu and Varis, 2007; Wang et al., 2012; Lu et al., 2015). The decreases of suspended solids and associated substances (C, N, P and $\mathrm{Si}$ ) loads can have serious consequences, such as increasing coastal erosion, reducing nutrient elements which provide foods for phytoplankton and aquaculture, decreasing aquaculture production, loss of shelter and breeding grounds... in coastal zone, as observed for numerous Asian rivers (Chen, 2000).

The same is likely to be true for the Red River where the impoundment of the large dams resulted in a clear decrease of both TSS concentration and fluxes in this study. Noted that a clear population and deforestation increases were observed for the Red River basin in the period 1960s-2010s (Le et al., 2015). This may approve the important role of dam impoundment in reducing suspended solids and associated nutrients transfer of the in the Red River to the coastal zone. The decrease of TSS and TON fluxes of the Red River may give different sequences (increased erosion, salinization of cultivated land or damaged ecosystems) in the coastal zone.

\subsection{Bias in our calculation}

Our calculations of TON concentration and flux of the Red River are subject to a number of possible biases when the TON concentrations were extrapolated from the relationship between TON and TSS concentrations given in (Le et al., 2005) with daily TSS concentrations obtained over the period 1960-2015. The use of this equation may not be suitable for the entire longterm period (about 55 years for the Red River), however, this bias is difficult for evaluating when no contemporaneous observation data exist. In addition, nitrogen transformation and lost towards the atmosphere as $\mathrm{N}_{2}$ was not considered in our calculation of the Red River TON fluxes transported to the coastal zone. However, despite these potential errors, the results presented here show the importance of the change in the Red River TON flux over the longterm period 1960-2015.

\section{Conclusion}

Longterm variation of TSS and TON concentrations and fluxes of the Red River were calculated for the period 19602015. The results showed that a clear decrease of both TSS and TON concentrations and fluxes of the three main tributaries and the whole Red River in this period due to a series of dams constructed in both China and Vietnam, especially for a recent period 2010-2015, in spite of population and deforestation increase in the whole basin.

For detail, spatial and seasonal variations of TSS and TON concentrations and fluxes of the Red River were clearly observed. The annual average of TSS concentrations spatially varied from $15 \pm 5$ to $1479 \pm 326$ whereas the annual average of TON concentrations spatially fluctuated from 0.41 to $3.19 \mathrm{mg} \mathrm{L}^{-1}$, averaging $0.98 \mathrm{mg} \mathrm{L}^{-1}$ for the whole period. Presently, the lowest values of both TON and TSS were detected for the Da River where several new dams (including the Son La and Lai Chau) appeared in the last decade 2010s. The higher TSS and TON concentrations were found in wet than in dry season for all sites during different periods.

Overall, the TSS fluxes of the Red River transferred to the estuary significantly decreased from $79 \times 10^{6} \pm$ $26 \times 10^{6} \mathrm{tyr}^{-1}$ (equivalent to a specific sediment yield of $\left.505 \pm 166 \mathrm{t} \mathrm{km}^{-2} \mathrm{yr}^{-1}\right)$ in the period 1960 s to $6 \times 10^{6} \pm 1 \times$ $10^{6} \mathrm{t} \mathrm{yr}^{-1}$ (corresponding to a specific sediment yield of $38 \pm$ $6 \mathrm{t} \mathrm{km}^{-2} \mathrm{yr}^{-1}$ ) in 2010s. Similarly, the riverine TON fluxes transferred to estuary significantly decreased from $141 \times$ $10^{3} \pm 38 \times 10^{3} \mathrm{t} \mathrm{yr}^{-1}$ (equivalent to $902 \pm 247 \mathrm{~kg} \mathrm{~km}^{-2} \mathrm{yr}^{-1}$ ) in 1960 s to $32 \times 10^{3} \pm 5 \times 10^{3} \mathrm{tyr}^{-1}$ (equivalent to $207 \pm$ $35 \mathrm{~kg} \mathrm{~km}^{-2} \mathrm{yr}^{-1}$ ) in 2010s. A strong decrease of TSS and TON fluxes of the whole Red River may give different sequences (increased erosion, salinization of cultivated land or 
damaged ecosystems) in the coastal zone of the Red River, as observed for numerous Asian rivers.

Data availability. Data is not publicly accessible.

Author contributions. LND and PTXB calculated TON fluxes. LND and LTPQ prepared the manuscript with contributions from all co-authors.

Competing interests. The authors declare that they have no conflict of interest.

Special issue statement. This article is part of the special issue "Hydrological processes and water security in a changing world". It is a result of the 8th Global FRIEND-Water Conference: Hydrological Processes and Water Security in a Changing World, Beijing, China, 6-9 November 2018

Financial support. This research has been supported by the Graduate University of Science and Technology /Ministry of Industry and Trade of the Socialist Republic of Vietnam (GUST.STS.ĐT 2020-MT01 /DTKHCN.008/19 project).

\section{References}

Beusen, A. H. W., Dekkers, A. L. M, Bouwman, A. F., Ludwig, W., and Harrison, J.: Estimation of global river transport of sediments and associated particulate $\mathrm{C}, \mathrm{N}$, and P, Global Biogeochem. Cy., 19, GB4S05, https://doi.org/10.1029/2005GB002453, 2005.

Chen, C. T. A.: The Three Gorges Dam: Reducing the upwelling and thus productivity in the East China Sea, Geophys. Res. Lett., 27, 381-383, 2000.

Dang, A. T.: The Red River Delta - The Cradle of the Nation, Hanoi National University Publisher, Hanoi, 53 pp., 2000.

Dang, T. H., Coynel, A., Orange, D., Blanc, G., Etcheber, H., and Le, L. A.: Long-term monitoring (1960-2008) of the riversediment transport in the Red River Watershed (Vietnam): Temporal variability and dam-reservoir impact, Sci. Total Environ., 408, 4654-4664, 2010.

Furuichi, T., Win, Z., and Robert, J. W.: Discharge and suspended sediment transport in the Ayeyarwady River, Myanmar: Centennial and decadal changes, Hydrol. Process. 23, 1631-1641, 2009.

Ha, V. K. and Vu, T. M. H.: Analysis of the effects of the reservoirs in the upstream Chinese section to the lower section flow of the Da and Thao Rivers, J. Water Resour. Environ. Eng., 38, 3-8, 2012.

Hu, B., Li, J., Bi, N., Wang, H., Wei, H., Zhao, J., Xie, L., Zou, L., Cui, R., Li, S., Liu, M., and Li, G.: Effect of human-controlled hydrological regime on the source, transport, and flux of particulate organic carbon from the lower Huanghe (Yellow River), Earth Surf. Proc. Land., 40, 10291042, https://doi.org/10.1002/esp.3702, 2015.
IMRR: WP3 report, Integrated and sustainable water Management of Red-Thai Binh Rivers System in changing climate (IMRR Project), 8 pp., 2010.

Ittekkot, V. and Zhang, S.: Pattern of particulate nitrogen transport in world rivers, Global Biogeochem. Cy., 3, 383-391, 1989.

Kummu, M. and Varis, O.: Sediment-related impacts due to upstream reservoir trapping, the Lower Mekong River, Geomorphology, 85, 275-293, 2007.

Le, T. P. Q., Billen, G., Garnier, J., Thery, S., Fezard, C., and Chau, V. M.: Nutrient (N, P) budgets for the Red River basin (Vietnam and China), Global Biogeochem. Cy., 19, 1-16, https://doi.org/10.1029/2004GB002405, 2005.

Le, T. P. Q., Garnier, J., Billen, G., Théry, S., and Chau, V. M.: The changing flow regime and sediment load of the Red River, Viet Nam, J. Hydrol., 334, 199-214, https://doi.org/10.1016/j.jhydrol.2006.10.020, 2007.

Le, T. P. Q., Billen, G., Garnier, J., Thery, S., and Chau, V.M.: Longterm biogeochemical functioning of the Red River (Vietnam): past and present situations, Reg. Environ. Change, 15, 329-339, https://doi.org/10.1007/s10113-014-0646-4, 2015.

Le, T. P. Q., Le, N. D., Dao, V. N., Rochelle-Newall, E., Nguyen T. M. H., Marchand, C., Duong, T. T., and Phung, T. X. B.: Change in carbon flux (1960-2015) of the Red River (Vietnam), Environ Earth Sci., 77, 658, https://doi.org/10.1007/s12665-018-7851-2, 2018.

Lu, X. X. and Siew, R. Y.: Water discharge and sediment flux changes over the past decades in the Lower Mekong River: possible impacts of the Chinese dams, Hydrol. Earth Syst. Sci., 10, 181-195, https://doi.org/10.5194/hess-10-181-2006, 2006.

Lu, X. X., Oeurng, C., Le, T. P. Q., and Duong, T. T.: Sediment budget of the lower Red River as affected by dam construction, Geomorphology, 248, 125-133, https://doi.org/10.1016/j.geomorph.2015.06.044, 2015.

Ludwig, W., Probst, J. L., and Kempe, S.: Predicting the oceanic input of organic carbon by continental erosion, Global Biogeochem. Cy., 10, 23-41, https://doi.org/10.1029/95GB02925, 1996.

Luu, T. N. M., Garnier, J., Billen, G., Orange D., Némery J., Le, T. P. Q., Tran, H. T., and Le, L. A.: Hydrological regime and water budget of the Red River Delta (Northern Vietnam), J. Asian Earth Sci., 37, 219-228, https://doi.org/10.1016/j.jseaes.2009.08.004, 2010.

MONRE: Report Annual on Hydrological Observation in Vietnam, Ministry of Environment and Natural Resources, Vietnam, 19602015.

MOSTE: Water quality - Determination suspended solids by filtration through glass-fibre filters, Ministry of Science, Technology and Environment, Vietnam, TCVN 6625:2000, 11 pp., 2000.

Moon, S., Huh, Y., Qin, J., and Nguyen, V. P.: Chemical weathering in the Hong (Red) River basin: Rates of silicate weathering and their controlling factors, Geochim. Cosmochim. Ac., 71, 14111430, https://doi.org/10.1016/j.gca.2006.12.004, 2007.

Pham, H. V.: Using ENSO information to improve the operation of the Hoa Binh reservoir, Vietnam, Master of Science in Environmental and Geomatic Engineering, Politecnico Di Milano, Italy, 70 pp., 2015.

Quach, X.: Assessing and optimizing the operation of the HoaBinh reservoir, Vietnam, by multi-objective optimal control techniques, $\mathrm{PhD}$ thesis, Politecnico di Milano, Italy, 138 pp., 2011. 
Syvitski, J. P. M. and Saito, Y.: Morphodynamics of Deltas under the Influence of Humans, Glob. Planet. Change, 57, 261-282, 2007.

Van Maren, D. S. and Hoekstra, P.: Seasonal variation of hydrodynamics and sediment dynamics in a shallows subtropical estuary: the Ba Lat River, Vietnam, Estuar. Coast Shelf Sci., 60, 529-540, 2004.

Wang, F. S., Wang, F. C., Zhang, J., Hu, H., and Wei, X. G.: Human impact on the historical change of $\mathrm{CO}_{2}$ degassing flux in River Changjiang, Geochem. Trans., 8, 7, https://doi.org/10.1186/1467-4866-8-7, 2007.

Wang, H., Yang, Z., Wang, Y., Saito, Y., and Liu, J. P.: Reconstruction of sediment flux from the Chanjiang (Yangtze River) to the sea since the 1860, J. Hydrol., 349, 318-332, https://doi.org/10.1016/j.jhydrol.2007.11.005, 2008.
Wang, X., Ma, H., Li, R., Song, Z., and Wu, J.: Seasonal fluxes and source variation of organic carbon transported by two major Chinese Rivers - The Yellow River and Changjiang (Yangtze) River, Global Biogeochem. Cy., 26, GB2025, https://doi.org/10.1029/2011GB004130, 2012.

Walling, D. E. and Fang, D.: Recent trends in the suspended sediment loads of the world's rivers, Glob. Planet. Change, 39, 111126, https://doi.org/10.1016/S0921-8181(03)00020-1, 2003.

Wu, Y., Zhang, J., Liu, S. M., Zhang, Z. F., Yao, Q. Z., Hong, G. H., and Cooper, L.: Sources and distribution of carbon within the Yangtze River system, Estuar. Coast Shelf Sci., 71, 13-25, https://doi.org/10.1016/j.ecss.2006.08.016, 2007.

$\mathrm{Xu}, \mathrm{J}$. and Yan, Y.: Effect of reservoir construction on suspended sediment load in a large river system: thresholds and complex response, Earth Surf. Proc. Land, 35, 1666-1673, https://doi.org/10.1002/esp.2006, 2010. 